яких у програмі робить іï, на нашу думку, небажаною для викладання у школах.

\title{
Гузенко Л.
}

\section{БОЛЬШАЯ ПЕРЕМЕНА: ЧТО ДЕЛАТЬ И С ЧЕГО НАЧАТЬ?}

Возможно, пришло то время на Украине, когда «педагогика, ставящая человека в центр всего, ныне безнадежно устарела» (А.Кордье). Возможно, пора помочь войти в школы трехмерному миру, где всеми вещами правит Бог и где Он определяет «меня», «тебя», «нас», «их».

Посланный нам Богом Президент поставил своей целью сделать перемену в философии школы на Украине. Получается, В.А Ющенко. имеет в своем сердце поставить перед украинским образованием ещё одну цель: дать нашим ученикам знания, необходимые для вечности. Станет ли осуществление этой цели болышой переменой, глубокой и основательной? Это зависит от нас - учителей-практиков, методистов, теоретиков, экспериментаторов, академиков и чиновников, всех , кого Бог призвал служить на ниве образования, «сеять разумное, доброе, вечное».

Мысли о том, что нашей украинской школе нужна перемена, вдохновили меня, учителя-методиста, открыть в 1999 году в г. Кременчуге Полтавской области частную школу «Логос». Мы объявили миссию школы: воспитание благочестивого поколения, формирование христианского мировоззрения и формирование родительской ответственности за воспитание детей перед Богом и государством. Конечно, нас объявили религиозной школой и всячески препятствовали нашему открытию, работе и признанию в городе, в обществе. По городу ползли слухи о том, что в школе только молятся и не дают крепких и прочных знаний, что, вместо базовых предметов, преподаются подпольно религиозные спецкурсы. Наш маленький педагогический коллектив стоически переносил внешние нападения и атаки, но не это было главной разрушительной силой и основным препятствием на пути роста и становления школы. Хочу здесь поделиться некоторыми выводами как директор, учредитель и просто учитель во время новаторской работы школы. Думаю, это будет интересно для благих намерений. Пусть этот опыт не был успешным (по финансовым причинам в 2004 году школа была закрыта), но любой жизненный опыт имеет ценность, а главное, 
имеет продолжение! Ведь если звезды зажигаются, значит, это кому-то нужно.

Что делать? Я уверена в том, что перед школой можно и нужно ставить две основные образовательные задачи:

1. Дать ученикам знания, умения, навыки, необходимые для жизни в обществе.

2. Дать ученикам знания, необходимые для вечности.

Мы забываем, что слово «образование» от слова образ и образовывать- это сформировать по образу и подобию Того, кто сотворил небо, землю и жизнь. Ученики должны понимать, кто, зачем и почему сотворил человека на Земле, каково место человека в замысле Божьем. Теория эволюции - это всего лишь теория, происхождение жизни с позиций креационизма - это Истина. И дети должны познать ее в школе параллельно с другими теориями.

С первой задачей наша система образования справляется хорошо и на мировом уровне выглядит достойно. Что делать для осуществления задачи второй? Я хочу подчеркнуть, что я говорю о школьном образовании и ни в коем случае не говорю о религиозном образовании. Религиозное образование - это образование, которое получают все желающие в духовных семинариях, колледжах для миссионерских и церковных служений различных конфессий и деноминаций. Я же говорю об общеобразовательной школе. Если в нашей системе народного образования этого не сможет выполнить массовая школа, то можно и нужно сформировать систему альтернативного христианского образования, которая возьмет на себя выполнение этих двух задач. Снова подчеркиваю, не религиозного.

С чего начать? Для реализации задачи второй нет необходимости введение обязательного предмета, например, «Закона Божсьего» или «Этики веры» - Наш опыт привел нас к мысли, что необходимо другой, более глубокий и трудоемкий путь - интеграция библейской истины во все школьные предметы. У нас остались свои и зарубежные наработки по этому направлению. Этому можно обучить каждого учителя, не исповедывающего атеизм как догму, а принимающего Библию как Послание Бога к человеку. Этому можно обучить учителя, открытого к познанию Истины. Достаточно учителей снабдить необходимой литературой, несколькими книжками по каждому предмету. У нас работали обычные учителя, не посещающие Церкви, но открытые к познанию библейской истины, принимающие мировоззрение креационизма. И у них получалось говорить о Творце Вселенной как о 


\section{8}

Великом Создателе, Мастере и Ученом, говорить с пониманием о законах математики и механики, литературных героях, исторических событиях с точки зрения библейских ценностей. Так $\mathrm{y}$ наших учеников формировалась ответственность за все происходящее на Земле, они вникали в суть Божьего замысла и научных законов, по которым Бог творил нашу жизнь. Ведь Творение Божье достойно того, чтобы его Изучать, Познавать, ведь для этого существуют науки и школьные предметы.

Почему я против введения предмета "Этика веры» или предмета» Закон Божий»? Великий реформатор Кальвин сказал: «Пришлите нам лес (учеников), а мы пошлем стрелы( учителей)». Сегодня в школе нет (откуда ему взяться после смутного времени) учителя, который смог бы преподать этот предмет, выполняя обещание Президента сохранить свободу совести и вероисповедания в Украине. Появится необходимость приглашать служителей храмов, пастырей, миссионеров, духовных лидеров с даром учителя и т.д. И этот преподаватель всегда и во всякое время будет представлять взгляды, учения своей конфессии, свято веря в истинность и непреложность вероучения. Наш опыт свидетельствует: говоря о вере, адвентист станет убеждать и учить по-адвентстски, баптист - по-баптистски, православный - по-православному, а католик - по-своему. Родители- протестанты начнут писать заявления о своем несогласии с преподавателем, если это противоречит их взглядам, православные и католики начнут настаивать на своем. В своей практике мне приходилось не раз мирить братьев и сестер, призывать их к тому, что всех объединяет, не обращать внимания, обходить те «подводные» камни, которые отличают конфессии.. Родители соглашались, но при этом забирали детей и переводили в школы, где вообще о Боге не говорилось. Словом, лучше никак, чем не по-нашему. Родители выясняли, сохраняли верность своей конфессии, а страдали дети. Я пережила боль утрат в своем нелегком служении детям. И мы отказались от услуг служителей церквей, пастырей.

Нужнн и полезно ввести предмет «Этика и мораль. Формирование характера».Главной задачей этого предмета обозначить: ознакомить учеников с основами христианской морали, заповедями Божьими; привить навыки выбора пути в решении непростых жизненных проблем; убедить детей в том, что человек свободен в своем выборе, но сам отвечает за добро и зло, за свой выбор перед ближними, государством и Богом.

Что главное в этом предмете? Любимый учитель. Дети нам говорили: «Сначала я полюбил учителя, потом полюбил его Библию, 
потом его Бога». Ни в коем случае нельзя превращать этот урок в назидательный Закон Божий. Вспомним, к чему привело преподавание Закона Божьего в царской России: к появлению великих атеистов инквизиторов и революции 17-го года, красному и белому террору. Значит, была допущена ошибка, к сожалению, историческая ошибка. Именно на этом уроке ребенок узнает, что Бог жив, что Он Творец и Отец. Дети узнают о том, что у Бога есть план на каждого из нас, что великая книга Библия - это открытое письмо Бога человеку, в котором Бог раскрывает тайны мироздания, поучает и дает нам руководство к жизни. Конечно, истории жизни библейских героев, их деяния, их отношения с Богом станут главными темами урока «Этика и мораль».

\section{Долюна ли икола переделать ученика, обязательно сделать} верующцм человеком? Дело в том, когда мы ломаем, заставляем, переделываем детей, мы превращаем маленькие личности в безголосые вещи. Бог создал детей, чтобы любить их и чтобы дети любили Его. Но наш Отец никогда не заставляет любить Себя. Помните, в Писании: «Пустите детей ко Мне...» т.е. приготовьте мою встречу с маленькой личностью, а основное слово мне ребенок должен сказать сам. Бог не создал душу мертвой, которая молчит, бездействует, ничего не видит, не слышит, не принимает решение, у нее нет выбора. Бог создал личность, которая растет, действует, принимает решение, размышляет, вступает в диалог, ошибается, делает выбор. Убедить ребенка, что вести диалог с Богом - это нормально, это хорошо, это весьма хорошо. Показать ребенку, что жить по заповедям можно и нужно, это настоящая жизнь. Рассказать о том, что выбор есть всегда, что выбор делает человек, результаты в жизни человека - это результаты его выбора. Главное, сформировать жизненные ценности, шаг за шагом, из класса в класс. Нельзя скрывать от детей то, какой ценой человек приобретает и отстаивает жизненные ценности. И, наконец, рассказать Великую Историю любви Бога к человеку и какую цену Бог заплатил за каждого из нас. Такова задача уроков «Этика и мораль. Формирование характера».

Допустим, вы считаете, что это не под силу системе государственных школ. У нас всегда есть выбор - одобрить появление тех школ, которые могли бы осуществить эти идеи в системе альтернативного образования. Более того, опекать эти школы на государственном уровне, поддерживать финансово, иначе их постигнет участь нашей школы. В мире идет война за умы и сердца молодого поколения. Наши школьные аудитории могут стать ареной самого успешного боя - боя за души детей. 
Если мы хотим собирать урожай каждый год - каждый год надо садить кукурузу. Если мы хотим собирать урожай в течение 10 лет - надо посадить сад. Если мы хотим собирать урожай в течение 100 лет - надо насаждать образование, т.е. формировать по образу и подобию. По какому образу и по чьему подобию? Ответ и выбор за нами, а результат выбора покажет время. Мудрый Соломон написал: «Пускай же глаза твои смотрят вперед». И пусть Сам Бог даст нам эту способность увидеть, предусмотреть и сделать правильный выбор. «Что пользы человеку приобрести весь мир, а себя самого погубить» (Мк 8:36). И как при этом не согласиться с Платоном, что «незнание Бога есть для государства наибольшим злом, и кто подрывает религию, подрывает и основы общества».

Докаш В., Позняк Я.

\section{СВІТСЬКА ТА ТЕОЛОГІЧНА ОСВІТА: ВЗАЄМОДІЯ ЧИ КОНФРОНТАЦІЯ?}

Якщо детально проаналізувати наше законодавство, то можна побачити, що тут наявні так звані “правові ножиці". 3 одного боку, законодавство гарантує свободу, урівнюючи в правах всіх громадян держави (ст.24 Конституції), a, 3 іншого, - залишає віруючих поза межами правового поля (ст.35 Конституції та ст.6 Закону України “Про свободу совісті та релігійні організації”), декларуючи відокремлення школи від церкви. Зазначимо, що навіть і Закон "Про освіту" не гарантує права на отримання альтернативної (не світської) освіти для дітей віруючих, незалежно від приналежності до релігійної організації, у навчальних закладах. Слід також відзначити, що навіть i в роки незалежності України ще не вирішено питання надання богословській освіті належного статусу, який урівнював би іiі в правах зі світською. Перепоною, знову ж таки, виступає принцип відокремлення школи від церкви. Тут постає декілька питань.

По-перше, чи можна засвоїти оту спадщину - релігію - тільки при однобічному (світському) підході до неї?

По-друге, якщо Основний та інші закони декларують право на свободу совісті, то вони повинні розширити ці права до можливостей альтернативних світській освіті закладів конфесійного типу та дозволу на 